\title{
The Socialization of Healthy Snack and Management of Pocket Money to Increase the Interest in Saving from Early Age in SDN Dumajah 1
}

\author{
Author \\ Wiwik Saidatur Rolianah (Orcid ID. 0000-0002-5541-2403), \\ Luluk Yuliati (Orcid ID. 0000-0002-5225-8703) \\ Correspondence \\ Islamic Economic Department, STEI Kanjeng Sepuh Gresik \\ Midwifery Department, Universitas Muhammadiyah Gresik \\ Islamic Banking Department, STEI Kanjeng Sepuh Gresik \\ kholid@steikassi.ac.id
}

Kholid Albar (Orcid ID. 0000-0001-6090-5862) , Lidia Aditama Putri (Orcid ID. 0000-0001-8402-2896),

\begin{abstract}
In Indonesia, the society's awareness of saving is still low, even though the public saving ratio is an indicator of economic growth. It is essential to introduce a culture of saving and investing from an early age to foster good habits until the child grows up. This community service activity aims to increase children's interest in protecting from an early age and educate students about the healthy snack.

The method used in this activity was through multidisciplinary counselling in the health aspect of healthy snacks and in the economic part of pocket money management to raise awareness to consume healthy snacks and increase students' interest in saving because it has reduced consumption of unhealthy snacks. A total of 33 students of SDN Dumajah 1 Bangkalan were targeted in this socialization.

The results obtained after the socialization were that knowledge about healthy snacks increased from $9,1 \%$ to $36,4 \%$, while students' interest in saving increased sharply from $0 \%$ to $87,9 \%$. The follow-up evaluation conducted six months after the socialization showed good results where the students previously did not have savings. Even all of them have savings with most of the nominal around Rp. 500,000, - to Rp. $700,000,-$. It means that multidisciplinary extension activities are effective in increasing children's interest in saving.
\end{abstract}

Keywords: Healthy Snacks, Management of Pocket Money, Interest in Early Saving

Received: 04 March 2021. Accepted: 22 June 2021

\section{Introduction}

Saving is an essential habit for every individual to do because saving has many benefits, and it is a way to prepare for a better future life. Saving is defined as keeping money in certain sum and a certain period (Murtani, 2019). Not only beneficial for personal life, according to Sukirno (2012) by saving money indirectly can help increase the economic growth of a nation.

The factors that influence economic growth are from investment and the circulation of money in society and depend on the level of society's saving ratio (Marlina \& Iskandar, 2019). However, unfortunately, society's interest to save money in Indonesia is still low. In 2017, Indonesia's level of saving ratio according to the Financial Services Authority of Indonesia (in Indonesian: Otoritas Jasa Keuangan or OJK) was only around $30,9 \%$ of the Gross Domestic Product (GDP) whereas Indonesia is targeting the saving ratio of $75 \%$ of GDP. The saving ratio of the Indonesian people is also still low compared to several countries in the Asian region, such as Singapore and China, which have reached $49 \%$ and the Philippines with a saving ratio of $44 \%$ (Olivia, 2019).

Based on the data above, it can be illustrated that the awareness of saving in Indonesia is still low. People in Indonesia 
generally do not prioritize saving their income when they first receive a salary. Still, they will only hold when there is some residual income that has been used for their daily needs. In addition, the large number of public perceptions that saving must be insignificant makes people lazy to save "small change", so in the end, the savings balance is empty (Pradhaniasti \& Meiyanto, 2012).

According to Zulaika \& Listiadi (2020), a person's saving behaviour is influenced by various factors, including selfcontrol, money management, pocket money and peer influence. Meanwhile, according to Suhendra \& Arifin (2019), Financial knowledge, subjective norm, attitude, and interest in saving are all factors that influence someone to hold.

The government has taken various ways to increase the society's saving ratio in Indonesia, including the "Let's Save" movement program launched by the government in 2016. The government also found banking products in saving accounts free of administrative fees and children's saving that significantly facilitate children's rescue from an early age at the BANK.

It is essential to introduce a culture of saving and investing from an early age to foster good habits until the child grows as an adult. Therefore, children need to be taught about financial management at early childhood age, so they have the proper knowledge and understanding of how to use and manage their finances; of course, this is adjusted to the child's age stage. According to Berk \& Winsler (1995), Early childhood is a period of children aged 0-8 years; at this age, children's motor and cognitive development develops very rapidly. For example, children at elementary school age can be taught to save some of their pocket money, so children get used to managing finances well from an early age. However, the phenomenon that occurs is that parents give separate savings and allowances to children; this is one factor that makes children not getting used to saving money on their own.

The culture of saving for students is still low, and the consumption level among students is still high. This statement is based on the preliminary study conducted in State Elementary School (in Indonesian: Sekolah Dasar Negeri or SDN) at SDN Dumajah 1 Bangkalan. Grade 1 elementary school students spend an average of Rp. 5000.00 per day, and there is no remaining money to save. The students have savings deposited with the class teacher, but the savings were given separately by their parents. In addition, out of 33 students in the class, not one $(0 \%)$ student has their piggy bank at home. If this habit pattern continues and is not understood from an early age, it can make adolescents and adults unable to manage their finances properly.

Efforts to increase the interest in saving among children can be made by providing counselling at an early age. Several previous volunteers have done some counselings, such as health counselling about building awareness of saving from an early age that Soviah (2019) conducted with the conclusion that most children $(90 \%)$ have an understanding of saving. Still, they did not save with their own pocket money because their parents have provided them with savings. After counselling was carried out, students understood the benefits of saving. Marlina \& Iskandar (2019) conducted other counselling for children at an early age in Rowosari Village showed that children were very enthusiastic and gave positive responses to save money, and children understood the importance of saving.

Counselling conducted to foster a habit of saving from an early age is a perfect activity. To be more effective, the counselling should be multidisciplinary. It would be better if children were taught the economic aspects of the benefits and importance of saving from an early age. Still, also children needed to be 
taught the health aspects of the importance of eating healthy snacks. Thus, children can understand those two aspects; then the can child avoid too many unhealthy snacks so the pocket money given by the parents do not run out for snacks and the children can save the remaining money.

Based on the background above, the service provider chose to carry out multidisciplinary counselling by conducting socialization on healthy snacks and management of pocket money in early childhood age in State Elementary School at SDN Dumajah 1 Bangkalan. This counselling aims to foster children's interest in saving from an early age and educate children about healthy snacks.

\section{Methods}

This Community Service (in Indonesian: Pengabdian Kepada Masyarakat or PkM) activity is located at SDN Dumajah 1, Tanah Merah District, Bangkalan Regency, with the target audience of grade 1 students. The problems at SDN Dumajah 1 students are the lack of interest in saving and the high consumption of unhealthy snacks. Therefore, the solution is to educate elementary school children about healthy snacks and pocket money management. After participating in this socialization, it is hoped that students will understand healthy snacks and management of pocket money to raise awareness to consume healthy snacks, and students' interest in saving will increase because it has reduced the consumption of unhealthy snacks.

The theme in this community service activity is related to health and the economy. In the health aspect, this community service activity provides socialization or counselling to students about healthy snacks. The counselling was conducted to increase students' understanding of healthy snacks and increase students' awareness in reducing unhealthy snacks. In the economic aspect, this community service activity provides socialization or counselling about pocket money management. The counselling was given to increase students' understanding of the importance of saving and how to manage pocket money so it can be used for keeping.

By providing knowledge to students included in the early childhood category, it is hoped that the awareness to adopt healthy eating habits will grow for future health and the understanding to practice saving habits from an early age will also increase to prepare for a better future.

This community service activity was carried out on January 27, 2020, at SDN Dumajah 1, Tanah Merah District, Bangkalan Regency. All grade 1 students at SDN Dumajah 1, as many as 33 students, were given counselling on healthy snacks and pocket money management through lectures and discussions. Then students were given stimulation of healthy snacks by providing nutritious food and stimulating the interest in savings from an early age by giving piggy banks to students.

The details of the stages of community service activities carried out by the volunteers were as follows:

1. Primary school survey that will be conducted by socialization

2. Collecting data about problems that occur in the school environment

3. Consultation and permission to conduct socialization

4. Preparation of material, method, and tool used for socialization

5. The implementation of socialization activities on healthy snacks and the management of pocket money

6. Evaluation of the performance of socialization activities

The assessment of this community service activity was carried out after the counselling ended. Still, the evaluation also continued 6 months after the activity took place by observing and supervising the students filling the piggy bank as their 
savings media. Data analysis was performed by using frequency distribution.

The media used during the socialization was MS. PowerPoint,

educational videos, paper, pens, healthy snacks, piggy banks.

\section{Result and Discussion}

The process of delivering the socialization material is carried out for grade 1 at SDN Dumajah 1 Bangkalan in the following order:

\section{Providing material about healthy snacks} and management of pocket money

The socialization material was given in two stages. The first stage of the material is about healthy snacks. The speaker conducts socialization about the importance of maintaining health through the food consumed, types of healthy and unhealthy snacks, the dangers of consuming unhealthy snacks, and ways to reduce and avoid unhealthy snacks. The second stage of the material is about the management of pocket money. The speaker delivered material about the importance of saving for the future, the benefits of saving, the value of funds, procedures for managing pocket money given by parents, and methods for keeping.

Previously, it was mentioned that grade 1 students at SDN Dumajah Bangkalan spent an average of Rp. 5,000 - per day, and not a penny of money was kept for savings. The aim of delivering this material was to understand healthy snacks and pocket money management, so students were expected to manage their snack consumption properly so the rest of their pocket money would be put into their savings.

When delivering the socialization material, all grade 1 students seemed enthusiastic about following the course of the material given. This can be seen from the image below:

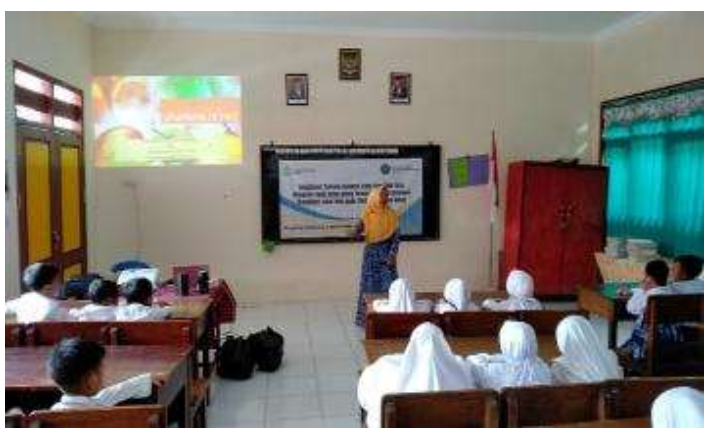

Figure 1. Healthy Snacks Socialization

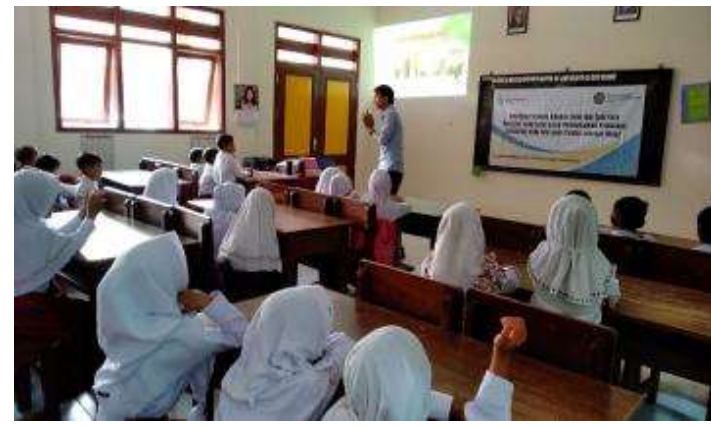

Figure 2. Management of Pocket Money Socialization

\section{Sing a song about healthy snack, and let's} save some money

After listening to the socialization material, students were shown a video about healthy snacks and let's save. Then students were asked to sing along following the footage

shown. This activity was done to stimulate their thoughts that eating healthy snack and saving are fun activities. By teaching healthy snack and saving songs to children, it was hoped that when this community service activity ended, the children would still remember the message the speaker conveyed through the music.

The students were very enthusiastic and cheerful in singing "healthy snacks" and "let's save money". The students also memorized the chant.

The following is the documentation when the students sang "healthy snacks" and "let's save: 


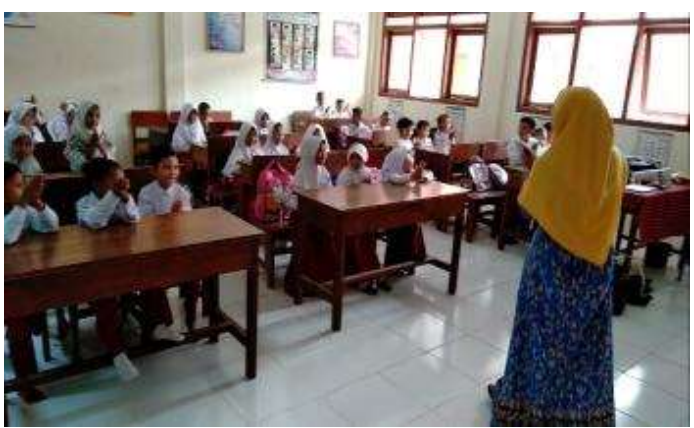

Figure 3. Students sang the "Healty Snacks" song

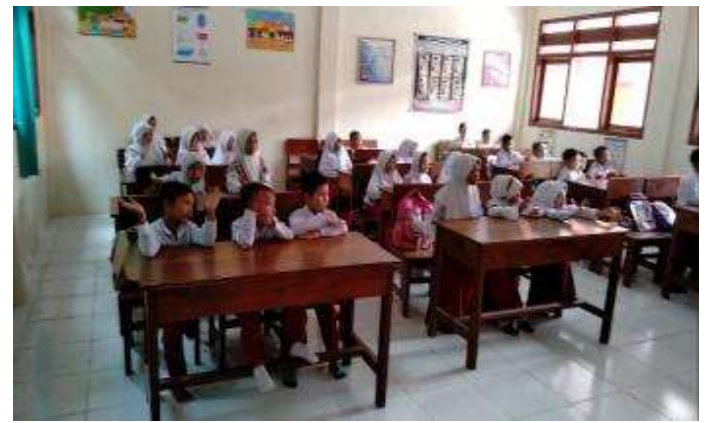

Figure 4. Students sang the "Let's Save" song

\section{Discussion, questions and answers}

After the delivery of the socialization material ended, students were then allowed to ask several questions related to the material that has been delivered. Out of the 33 students, four students asked questions. The speaker gave feedback by providing the opportunity for other students to answer then the speaker completed the answer.

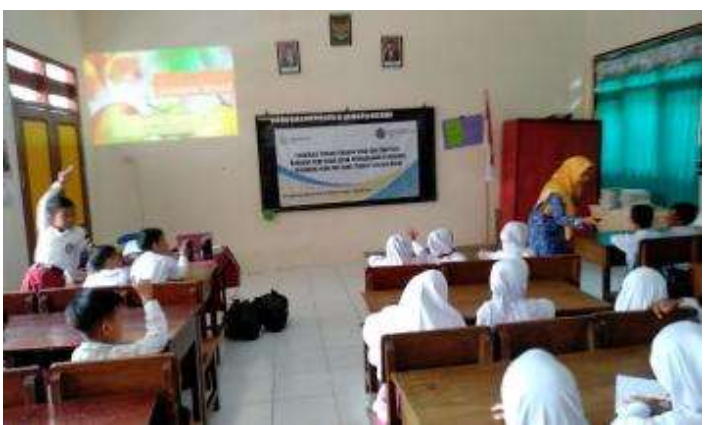

Figure 5. Students discussion

\section{Evaluation of the understanding of the material}

To determine how far the students understood the socialization material delivered, students are given a closed question sheet to find out their understanding of the material and their interests regarding the consumption of healthy snack and saving habits. According to information from the class teacher, all grade
1 students could read and write well. Before counselling was carried out, students were first given a pre-test with simple closed questions to determine students' knowledge and interest in healthy snacks and essential financial management.

An overview of students' knowledge and interests about healthy snacks and financial management can be seen in the table below:

Table 1. The Knowledge of Grade 1 Students Before and After Socialization of Healthy Snack

\begin{tabular}{lcccc}
\hline \multirow{2}{*}{$\begin{array}{c}\text { Knowledge } \\
\text { level }\end{array}$} & \multicolumn{3}{c}{ Healthy Snack Socialization } \\
\cline { 2 - 5 } & \multicolumn{2}{c}{ Before } & \multicolumn{2}{c}{ After } \\
\hline Good & $\mathrm{N}$ & $\%$ & $\mathrm{~N}$ & $\%$ \\
Fair & 3 & 9,1 & 12 & 36,4 \\
Poor & 12 & 36,4 & 16 & 48,5 \\
\hline \multicolumn{1}{c}{ Total } & 18 & 54,5 & 5 & 15,2 \\
\hline
\end{tabular}

Table 1 showed that the students' knowledge about healthy snacks before being given socialization and after socialization. Based on the results from the table above, it can be concluded that most students have less knowledge about healthy snacks $(54,5 \%)$. Still, after being given socialization, the students' knowledge about healthy snacks increased, so most students had good knowledge about healthy snacks $(36,4 \%)$.

Table 2. The Interest of Grade 1 Students to Consume Healthy Snack

\begin{tabular}{lcccc}
\hline \multirow{3}{*}{ Interest } & \multicolumn{3}{c}{ Healthy Snack Socialization } \\
\cline { 2 - 5 } & \multicolumn{2}{c}{ Before } & \multicolumn{2}{c}{ After } \\
\cline { 2 - 5 } & $\mathrm{N}$ & $\%$ & $\mathrm{~N}$ & $\%$ \\
\hline Positive & 7 & 21,2 & 22 & 66,7 \\
Negative & 26 & 78,8 & 11 & 3,3 \\
\hline \multicolumn{1}{c}{ Total } & 33 & 100 & 33 & 100 \\
\hline
\end{tabular}

Table 2 showed that the interest of grade 1 students to consume healthy snacks before being given socialization was primarily negative, which means that 26 students $(78,8 \%)$ were more interested in consuming unhealthy snacks. Meanwhile, after being given socialization, students' interest in consuming healthy snacks increased to be positive. As many as 22 students $(66,7 \%)$, most of the students have a positive interest in consuming healthful snacks. 
Table 3. The Knowledge of Grade 1 Students Before and After Being Given the Socialization of Financial Management

\begin{tabular}{lcccc}
\hline \multirow{2}{*}{ Knowledge level } & \multicolumn{3}{c}{ Healthy Snack Socialization } \\
\cline { 2 - 5 } & \multicolumn{2}{c}{ Before } & \multicolumn{2}{c}{ After } \\
\cline { 2 - 5 } & $\mathrm{N}$ & $\%$ & $\mathrm{~N}$ & $\%$ \\
\hline Good & 7 & 21,2 & 19 & 57,6 \\
Fair & 10 & 30,3 & 9 & 27,3 \\
Poor & 16 & 48,5 & 5 & 15,1 \\
\hline \multicolumn{1}{c}{ Total } & 33 & 100 & 33 & 100 \\
\hline
\end{tabular}

Table 3 showed that students' knowledge about the management of pocket money was poor before being given the socialization, namely as many as 16 students $(48,5 \%)$. Meanwhile, the students' knowledge about pocket money management after being given socialization was increased, namely as many as 19 students $(57,5 \%)$.

Table 4. The Interest of Grade 1 Student in Saving

\begin{tabular}{ccccc}
\hline \multirow{2}{*}{ Interest } & \multicolumn{3}{c}{ Healthy Snack Socialization } \\
\cline { 2 - 5 } & \multicolumn{2}{c}{ Before } & \multicolumn{2}{c}{ After } \\
\cline { 2 - 5 } & $\mathrm{N}$ & $\%$ & $\mathrm{~N}$ & $\%$ \\
\hline Positive & 0 & 0 & 29 & 87,9 \\
\hline Negative & 33 & 100 & 4 & 12,1 \\
\hline Total & 33 & 100 & 33 & 100 \\
\hline
\end{tabular}

Table 4 showed that students' interest in saving increased by $87,9 \%$ after being given socialization about pocket money management. Before being given the socialization, no one of the students $(0 \%)$ was interested in saving.

\section{The distribution of healthy snacks and piggy banks}

The volunteers distributed healthy snacks to students to show that even healthy snacks were also delicious and more nutritious than unhealthy snacks. In addition, bringing a packed meal from home or buying healthy snacks was a perfect thing to do so children could avoid illness and keep their allowance for savings.

The volunteer then distributed the piggy bank to students to provide stimulation and media for students so the students could save their remaining pocket money. The volunteer and service provider delivered information to students to open the piggy bank six months later and reported to the homeroom teacher how much savings the students had collected. This stage was done to evaluate how far the community service activity has succeeded in

increasing students' interest and awareness of saving from an early age.

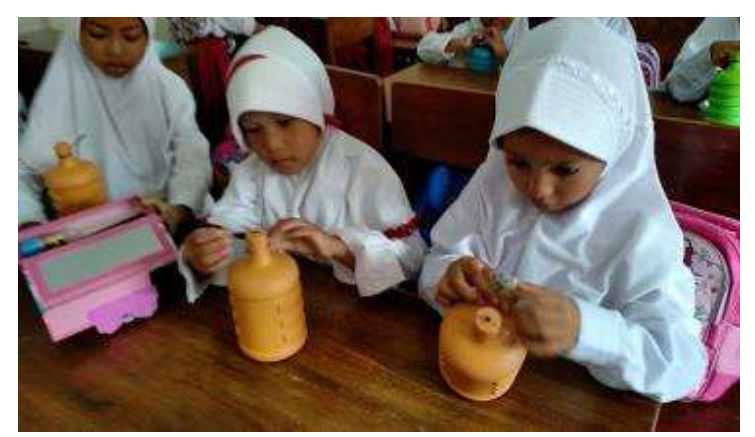

Figure 6. Students are Enthusiastic to Fill the Piggy Bank

\section{The Evaluation of Community Service Activities}

The Covid-19 pandemic that has entered Indonesia starting in early March 2020 has made volunteers and service providers unable to make direct visits to SDN Dumajah 1 Bangkalan. Unfortunately, we could not reach the SDN Dumajah 1 Bangkalan through the Virtual Zoom application due to network problems. Teaching and learning activities during the Covid-19 pandemic at SDN Dumajah 1 Bangkalan were carried out through the WhatsApp Group.

These obstacles that the researchers and service provider, and volunteer encountered did not prevent continuing and carrying out evaluations after the socialization of community service activities that we conducted six months ago. The researchers asked for the help of the grade 1 homeroom teacher, Mrs Sufrijah, S.Pd., (in English: Bachelor of Education or BEd), to give direction toward the children and their parents to open their piggy banks which already gave six months ago as the media for saving. 


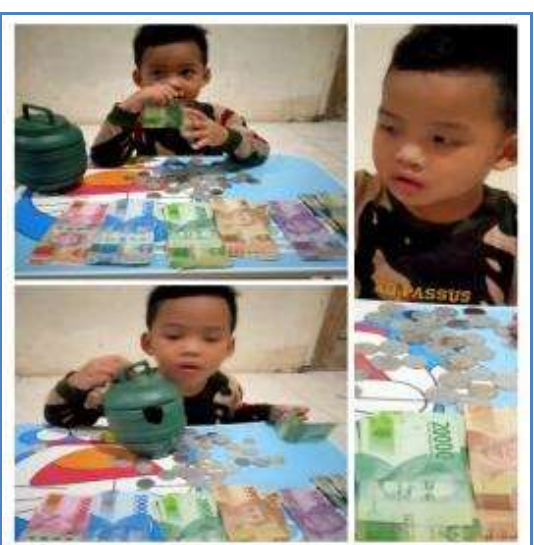

Figure 7. The Documentation of SDN Dumajah 1 Student When Open His Piggy Bank

Based on the data collected by the homeroom teacher about the amount of savings that students got after the piggy bank was opened, it can be described briefly in the graph below:

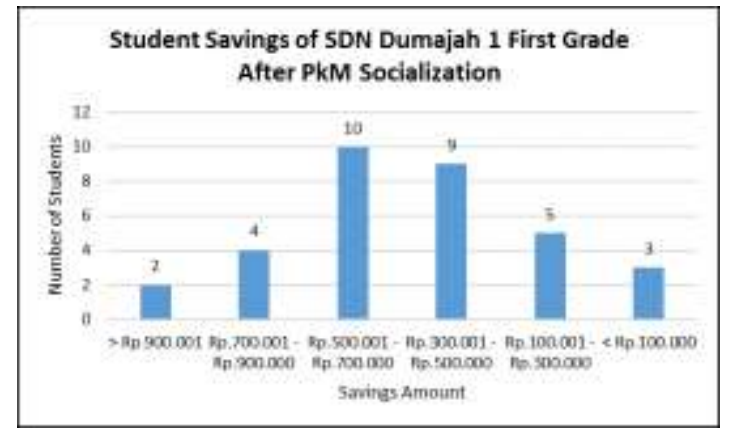

Figure 8. homeroom teacher about the amount of savings that students got after the piggy bank.

The socialization process for healthy snacks and pocket money management went very well; all participants seemed enthusiastic and took an active role in following the activity until it was finished. The evaluation of students' knowledge about healthy snacks increased from $9,1 \%$ to $36,4 \%$. The results of the review of students' interest in saving were also outstanding, where the results showed that as many as $87,9 \%$ of children had an interest in saving after socialization, and this was also evidenced by the amount of savings that students had opened six months later after the socialization was conducted. Most of them had savings of five hundred to seven hundred thousand rupiahs. This means that this multidisciplinary socialization activity was considered effective in changing children's behaviour in managing finance.

Even though grade 1 students only did online learning at home, this also did not make students asked for daily allowances as their habit like when they went to an offline school. The children still asked for pocket money to buy snacks at the shop near the house; some of it was also used to put them in the piggy bank. The intensity of children's snack had decreased significantly than before the pandemic because they studied more at home, the children ate more healthy snacks at home. This is the description of an interview with the guardians of students through the Whats App Group.

Based on Figure 9, it could be seen that most children have savings with the nominal range of Rp. 500,001, - up to Rp. 700,000, after the piggy bank that the service provider gave was opened, as many as ten children. This means that the service provider's socialization activities positively impact students to make saving habits from an early age. The students who previously didn't even have a dime in savings now have even a thousand hundreds rupiah in their piggy bank. This is in line with what was conveyed by (Klontz \& Klontz 2009) that a person's experience will determine how he or she manages finances. The experiences of students who have learned how to manage money and practice it directly so far have a powerful influence on their financial behaviour when they grow up.

Furthermore, the service provider hoped that the results of this activity would continue to be a good habit for children to continue saving as well as for parents who have been accompanying children to encourage their children to preserve and provide savings media, for example in the form of a piggy bank or savings account at the BANK. In addition, the service provider also hoped that the results of this activity would continue to be consistently carried out by children in terms of eating healthy and nutritious food and snacks even though they have returned to study in school later. 


\section{Conclusions}

The socialization process for healthy snacks and pocket money management went very well; all participants seemed enthusiastic and took an active role in following the activity until it was finished. The evaluation of students' knowledge about healthy snacks increased from $9,1 \%$ to $36,4 \%$. The results of the assessment of students' interest in saving were also excellent, where the results showed that as many as $87,9 \%$ of children had an interest in saving after socialization, and this was also evidenced by the amount of savings that students had opened six months later after the socialization was conducted. Most of them had savings of five hundred to seven hundred thousand rupiahs. This means that this multidisciplinary socialization activity was considered effective in changing children's behaviour in managing finance.

\section{References}

Berk, L. E., \& Winsler, A. (1995). Scaffolding Children Learning: Vygotsky and Early Childhood Education. New York: NAEYC.

Klontz, B., \& Klontz, T. (2009). Mind Over Money Mengatasi Kelainan Keuangan Yang Menggerogoti Kesehatan Finansial. Jakarta: Elex Media Komputindo.

Marlina, N., \& Iskandar, D. (2019). Gerakan menabung sejak dini di rowosari. Pengabdian Vokasi, 01(01), 27-32.

Murtani, A. (2019). Sosialisasi Gerakan Menabung. Seminar Nasional Hasil Pengabdian Kepada Masyarakat 2019 Sindimas, 1(1), 279-283.

Olivia, G. (2019). Darmin: Rasio Menabung yang Rendah Membuat Indonesia Makin Bergantung Pada Dana Asing. Nasionalkontan.Co.Id. Retrieved from https://nasional.kontan.co.id/news/darminrasio-menabung-yang-rendah-membuatindonesia-makin-bergantung-pada-danaasing\#: :text=Rasio tabungan (saving ratio) Indonesia,49\%25 dan Filipina 44\%25.

Pradhaniasti, R. R., \& Meiyanto, S. (2012). Dinamika Pengambilan Keputusan Menabung Pada Pedagang Kecil di Pasar Gede Surakarta (Universitas Gajah Mada). Retrieved

from http://etd.repository.ugm.ac.id/home/detail_ pencarian/56397

Soviah, O. F. (2019). Penyuluhan Membangun Kesadaran Menabung Sejak Dini Pada Siswa

Sdn 2 Lengkong Wetan Kelurahan. Prosiding Seminar Nasional Pengabdian Masyarakat LPPM UMJ, (September), 1-6.

Suhendra, Y. F., \& Arifin, A. Z. (2019). Faktor Yang Memprediksi Perilaku Menabung Pekerja Di Jakarta. Jurnal Manajerial Dan Kewirausahaan, I(3), 600-608.

Sukirno, S. (2012). Makroekonomi Teori Pengantar. Jakarta: Rajawali Press.

Zulaika, M. D. S., \& Listiadi, A. (2020). Literasi Keuangan, Uang Saku, Kontrol Diri, dan Teman Sebaya Terhadap Perilaku Menabung Mahasiswa. Ekuitas: Jurnal Pendidikan Ekonomi, 8(2), 137-146. 